\title{
QUEEN'S
UNIVERSITY
BELFAST
}

\section{Lost and Found? A Parable of the Architect (Male) and the Academic (Female)}

Morrow, R., \& Fitzgerald, J. (2016). Lost and Found? A Parable of the Architect (Male) and the Academic (Female). In J. B. Brown, H. Harriss, R. Morrow, \& J. Soane (Eds.), A Gendered Profession: The Question of Representation in Space Making (pp. 72-78). RIBA Publishing, London. http://www.ribabookshops.com/item/agendered-profession/87837/

Published in:

A Gendered Profession

Document Version:

Publisher's PDF, also known as Version of record

Queen's University Belfast - Research Portal:

Link to publication record in Queen's University Belfast Research Portal

Publisher rights

Copyright 2016 RIBA Publishing

This work is made available online in accordance with the publisher's policies.

\section{General rights}

Copyright for the publications made accessible via the Queen's University Belfast Research Portal is retained by the author(s) and / or other copyright owners and it is a condition of accessing these publications that users recognise and abide by the legal requirements associated with these rights.

Take down policy

The Research Portal is Queen's institutional repository that provides access to Queen's research output. Every effort has been made to ensure that content in the Research Portal does not infringe any person's rights, or applicable UK laws. If you discover content in the Research Portal that you believe breaches copyright or violates any law, please contact openaccess@qub.ac.uk. 
EIGHT

LOST AND FOUND? A PARABLE OF THE ARCHITECT (MALE) AND THE ACADEMIC (FEMALE)

John Fitzgerald and Ruth Morrow 

between a practising architect (male) and an architecture academic (female and feminist). This is a conversation between two longstanding friends who did their Part 3 professional exam together more than 25 years ago. Since then, they have taken different career paths and lived at different paces and in different places. Every so often they meet over coffee to laugh and argue about architecture, bemoan failures, and share successes.
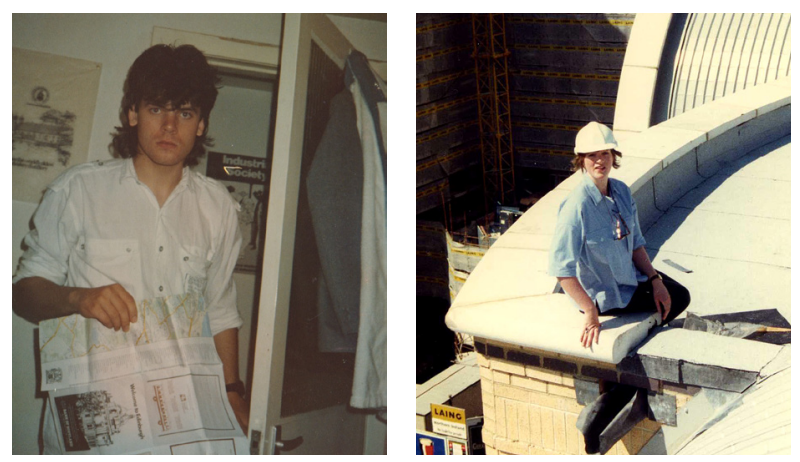

\section{Ruth Morrow and John Fitzgerald as students}

The academic initiated the interview in order to hear an honest and open account of the career experience of a male architect. She hoped that their longstanding friendship would lead to less guarded responses. The answers to the questions were always going to be personally challenging to the interviewer and possibly to their friendship. The interview is a form of ethnographic study: a structured, qualitative process within a long term, immersed context. But when 'the immersed context' is a much-valued friendship, it is a precarious action. Nevertheless, for the future of gendered relationships both protagonists accepted the risks.

John is an architect, born, educated and working in Belfast, aside from some years working in London and Dublin. Now in his early 50s, he experienced the Troubles of the 1970s and '80s and the slowly emerging peace process. ${ }^{1}$

\section{THE INTERVIEW}

\section{WHEN DID YOU START THINKING ABOUT BEING AN ARCHITECT?}

I had really no interest in being an architect as a child. My father was an architect, but I was so distracted by life that I wasn't even curious about a career. However, when it came to making decisions I thought about my father's work and gained a place studying architecture at a local university in 1983, probably because there were a few unfilled spaces, and potentially because of my father's reputation. So I sort of fell into architecture. I wasn't pushed and I didn't push myself. I probably understood architecture by some sort of osmosis: being in and out of Dad's office and, like all architect's children, on holiday we were photographed in front of buildings, for scale. It wasn't an alien world. I wouldn't say I was comfortable with it but I was familiar. That familiarity might have been a trap since my exposure to architecture was through a very traditional type of practice, pretty much unchanged since the 1940s. 


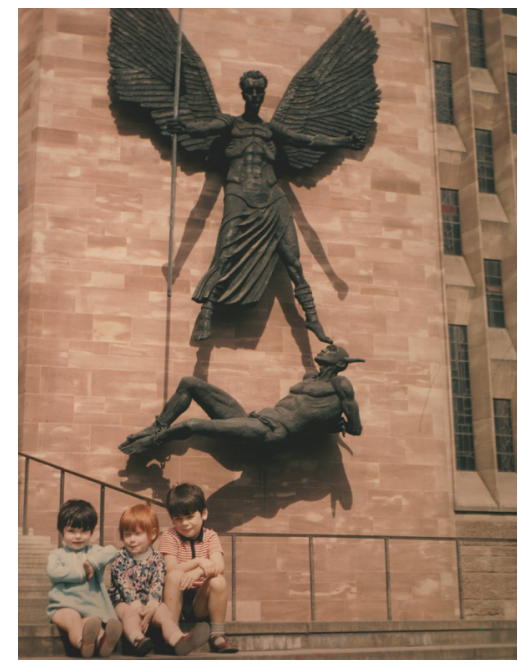

John and siblings in front of building, for scale

\section{WHAT WAS YOUR EXPERIENCE OF STUDYING ARCHITECTURE?}

My first year was spent in the family home, a financial necessity at the time. I dipped my feet into the architectural pool and was (for the most part) found wanting. My dad tried his best to stay distant from my work but by the end of first year we both agreed it would be better if I moved out and into a shared house with other architectural students.

For my year out, I went to Edinburgh to work for a friend of my father. Dad negotiated my salary, which was famously so low that I qualified for free meals and housing benefit. It was a very commercial office and everyone seemed to be old and divorced - or at least lead complicated lives. It was a strangely adult place and none of the skills I had learned in university were of any use.

By the time I began postgraduate studies, my peers and I were becoming increasingly disillusioned with the tutoring we were receiving. As a result, we looked to the library and read every magazine to hand, the AA Files being a personal favourite. It was at this time I became aware of the parochialism of my hometown. The architectural world I was reading about was more interesting and more dynamic outside Northern Ireland. As a result, and once again at my father's suggestion, I worked in London during summers, and when I graduated from Part 2 I took up a position there. I returned to Belfast in 1990 to take up a full time position in a well-established, commercial office. I was convinced by colleagues to buy a house. But one year later I was made redundant. I had passed through college and the early stages of employment as if on a conveyor belt and by the age of 26 I had considerable financial responsibilities. Nevertheless, I got another job within a week. I found the pressure to hold onto a paying job almost unbearable. I had not witnessed my father in that situation. This professional instability was never mentioned when we studied, but I have come to realise that people who end up in architecture offices are simply survivors. Within a few years the recession hit again and with only the prospect of kitchen extensions and refurbishment projects, I began to look further afield for work. 
THAT WAS AROUND THE TIME OF THE CEASEFIRE. DID THAT CHANGE ANYTHING FOR YOU? 2 Yes, there was a change in atmosphere. Ironically I began to think about leaving, this time not to London but to Dublin. Being a sectarian half-breed, neither protestant nor catholic, I wanted to investigate what it was to be Irish. So I worked in Dublin for the next six years, returning to Belfast just before the turn of the millennium. My decision to return home was the result of several factors, but most significantly my sister had just had a daughter and I wanted to be nearby.

It was two years after the Good Friday agreement and things were beginning to change in Belfast. I ended up with five job offers and accepted a role in one of Belfast's most established offices. My new office had been awarded the contract for a very significant building in Belfast and I was given the role of project architect. I worked very hard on the project and at the end I was rewarded with the offer of becoming a practice associate. Two years later I was bought in as a salaried partner but with no equity in the practice. It was 2007, the start of the financial crisis, and the phones simply stopped ringing. Fortunately, we were completing work on apartments for a large development, but we won no new work. It was an unprecedented period. None of my fellow partners had the skill set to deal with it gracefully. A whole generation of architects had been educated and started their careers without any understanding of the possibility of recession. Our staff had become used to annual salary increases of $10-15 \%$. Many had second homes and young families and I was given the responsibility of handling their redundancies.

I CAME BACK TO BELFAST IN 2003 AND WE MET UP OCCASIONALLY. I COULDN'T ALWAYS RECOGNISE THE JOHN I HAD KNOWN. THE RESPONSIBILITY OF EMPLOYING PEOPLE SEEMED TO WEIGH HEAVILY ON YOU BUT I NEVER THOUGHT YOU WOULD GIVE UP THE 'BIG JOB.' WHAT CAUSED THAT CHANGE?

I met Rita and I became a husband at 45 and a father at 46 . When my two-yearold daughter said she missed me, I thought, 'I don't want to be missed by my daughter!' So despite the fact that there was nothing happening in the construction industry, I decided to set up practice on my own. In my previous role I could never have let my family life influence my work life. It wouldn't have been acceptable to start later after dropping a baby to childcare.

The first year in my own office was abysmal, financially and architecturally. By the third year, things were good. Alongside that, my wife has a successful job that

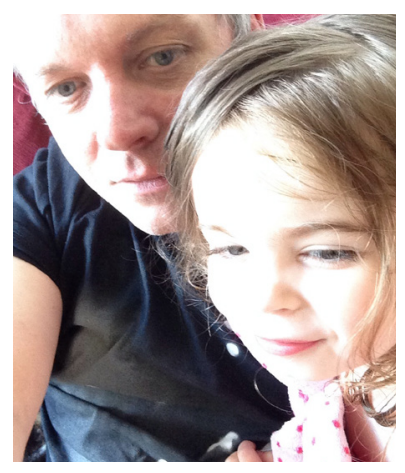

John and daughter, Ellie 
requires a flexible partner. I would not be able to support her career if I wasn't in charge of my own time. I have worked for 30 years and I only spent one-sixth of that married with a daughter. Architecture stopped me from settling down: it delayed my maturity and stopped me making sensible decisions about relationships. I just spent so much time working. I regret that.

\section{WHAT INTERESTS YOU AS A MAN ABOUT YOUR PROFESSION?}

At the opening of one of my projects I was honoured to be introduced to the poet Seamus Heaney. He said that he always thought of construction as a very fraternal occupation and I agreed. Construction is about men 'doing stuff': men bringing materials to site, men lifting, and men fixing it into place. It's a male industry and the architect is traditionally the top dog (or was). Being the top male in a male industry makes you an alpha male, not by nature but by profession. I have spent most of my working life in these all male environments. It's comfortable. I understand that more now when I go into predominantly female areas. The comfort goes. And I don't know if it's a gender comfort or whether it is because I am just not used to it.

\section{WHAT ARE THE ADVANTAGES OF BEING A MAN IN ARCHITECTURE?}

I'd say that the advantage is that I don't need to think about it! The only way for me to consider that question is by thinking about what it would be like not being a man. And that's about overcoming prejudice in construction industry. There are many things that make it difficult to get your voice heard - some of which are gender neutral - like age and ethnic background, and whether you speak with a local accent or not. I have witnessed that with migrant architects in Belfast, and it was my own experience as an Irish architect in London. But is that the same as being a woman? I am not certain. It seems to be that as a man there are far fewer obstacles. I went to an all male school and ended up working in almost all male environments, so in one way that is all that I know. It's like being removed from reality.

\section{WHAT ARE THE DISADVANTAGES OF BEING A MAN IN ARCHITECTURE?}

I think women are at least two generations into a reimagined position in society; men are not at that point yet. From my perspective, my male role models worked hard and played hard, providing financial stability to the family often long into retirement. But at what cost to their happiness and well being? Still to this day I know of very few men who are primary carers for their children. Most men continue to lead professional lives in the same manner as their fathers. It was only the unsolicited economic recession that jolted me out of this traditional role and made me realise what I was missing by practising my profession in such a manner. I can say that I had, on paper, a successful traditional architectural career up to the point where I left my old practice. I had won a few RIBA awards and successfully designed and managed large-scale projects, but the price I paid was a delayed family set up, ill health, and my removal from the wider community. This is the disadvantage of being a man, I think: the pressure to conform to traditional role models means you sometimes make decisions that distance you from happiness and a full life.

\section{CAN YOU IMAGINE WHAT IT'S LIKE TO BE A WOMAN IN OUR PROFESSION? AND DID YOU EVER DO SOMETHING TO SUPPORT FEMALE COLLEAGUES?}

Well, light still works the same way, space is the same, shadow is the same. I don't see how a woman would look at, or experience, architecture differently from a man.

\section{A GENDERED PROFESSION}


Is it the practice of architecture that is different? Would a woman look at something differently to a man? As a man I must unwittingly design a world that suits me - so I suppose women must do it differently.

As an employer, I have never noticed the difference between the work of women or men, but then I may never have created a work environment where those characteristics could gestate or flourish. I am proud that in my previous practice I was involved in establishing a decent level of maternity pay. As a result of some of the misogynistic practices I have witnessed, I have often found myself taking the side of women. I have witnessed women being unfairly targeted for redundancy; criticised for doing stuff that men were no better at; and overlooked for positions of responsibility in favour of men. And because I saw that I became an accidental defender of women in the office. That has obviously been compounded now by having a daughter, so I try to understand the world through a women's eyes.

\section{IS THERE A REGIONAL EFFECT TO YOUR EXPERIENCE OF PRACTICE?}

As you walk to the Belfast departure gate in Heathrow after being in London on business, a kind of ethnic filtering takes place. The passengers become less and less culturally and gender diverse, and increasingly white and male. That pretty much reflects the conservative and traditional nature of the region. Northern Ireland is a very peculiar cultural and economic entity. Much of the architectural work is driven by the public sector and this, in turn, is carried out by traditional practices. I went to a construction event in London 2011 when they were talking about the 2009 recession in historical terms and yet today (2016) in Northern Ireland we are still very much in a recession.

\section{IN OUR EARLY DISCUSSIONS YOU TALKED OF THINGS YOU HAD LOST AND FOUND THROUGH YOUR EXPERIENCE OF ARCHITECTURAL PRACTICE - COULD YOU DWELL SPECIFICALLY ON WHAT YOU HAVE FOUND? \\ To be an architect you have to have empathy with everybody around you: your family, wider society, and your client. So spending life in a bubble simply to hit the next deadline means you don't fully experience the world or understand how others experience it. I think it's best to limit your financial burdens in early life to allow you greater freedom to exercise and practise your architectural ability. I now understand that there are stages of revelation in architecture that allow you to reinvent yourself at different periods. So if you haven't flourished at 30 or 40 there is still plenty of time. \\ If the next generation of architects can create an architectural career that suits their personal lives - i.e. choosing to work in places not because you have to but because you want to be there - then it would alter the whole machinery of professional practice.}

\section{REFLECTING ON THE INTERVIEW:}

The process of interviewing a peer and friend was challenging. I could have predicted many of the experiences and perceptions that John spoke of as a man in the profession - I had witnessed some of them first hand when we met over the years, but I also knew it, or thought I knew it, from the feminist literature I had read.

When he spoke of the support of his father, the sense of fraternity, of being a top dog, and his general sense of good fit to the profession, I struggled. These are things I've never experienced. But rather than interrupt, I continued to listen. 
When he spoke about all male environments as 'comfortable', I found myself imagining that comfort, trying to hold onto it as one holds on to the duvet on chilly mornings. I thought about how unsettling it was to disrupt comfort and I almost empathised. But the sense of comfort one has in a mono-gendered context is only possible by the exclusion of the other gender - it is, as John acknowledges, "like being removed from reality': a position entirely unsustainable, especially when your profession serves society. But John also echoed this in his candid description of his work-life imbalances and the pressure of working in a financially unstable profession. As he continued talking, my reaction softened. I heard instead his struggle to make sense of the work environment, how he had shifted priorities and refocused on things that mattered to and impacted on him and his family. What I had thought was his privilege has, at times, been his trap. As a woman in architecture, there are no rules for me to stick to, no conventions or traditions that resonate so strongly that I can't challenge or upturn them. Architecture, for me, is whatever I want it to be. But for John, it has been a genuine endeavour to reforge another way to practise. I understand that better from listening to him.

And whilst John might not have fully resolved whether or how women act differently as architects, it's clear that his own sense of being a 'sectarian hybrid', an Irish architect in London, and a practitioner in a provincial UK city, has allowed him to know what it is to be outside the norm. It's in the complex multi-layered identities that we all have, beyond gender, where we find empathy for those who are excluded.

This parable of the male architect and the female academic concludes with two observations. Firstly, that as individuals across the gender spectrum, we should listen more to one another, constructing moments for open, direct and, indeed, directed conversations. Sometimes we need to ask those questions we think we already know the answers to; the results can be enlightening. And secondly, as a community we need to listen to a wider range of practitioners, since we are much more than a gendered profession.

1 See paper co-authored by John, Ruth and Ciaran Mackel on subject of the challenges of the profession post-conflict: Morrow, R., Mackel, C. \& Dickson Fitzgerald, J. 'Beyond the shadow space: architecture as a professional and creative process; during and post-conflict', Journal of Architecture, 16/1, March 2011, $57-70$.

2 In 1994 a series of ceasefires were called by the various paramilitary groups in Northern Ireland. This was the start of the peace process that was more formally brokered in April 1998 by the Good Friday Agreement, also called the Belfast Agreement. 